\title{
Praktyczne aspekty diagnostyki i leczenia zakrzepowej plamicy małopłytkowej
}

\author{
Practical aspects of diagnosis and treatment \\ of thrombotic thrombocytopenic purpura
}

\author{
Magdalena Górska-Kosicka1 ${ }^{1}$ Jerzy Windyga ${ }^{1,2}$ \\ ${ }^{1}$ Klinika Zaburzeń Hemostazy i Chorób Wewnętrznych, Instytut Hematologii i Transfuzjologii, Warszawa \\ ${ }^{2}$ Zakład Hemostazy i Chorób Metabolicznych, Instytut Hematologii i Transfuzjologii, Warszawa
}

\begin{abstract}
Streszczenie
Zakrzepowa plamica matoplytkowa (TTP) charakteryzuje się występowaniem triady objawów małoptytkowości, niedokrwistości hemolitycznej i niedokrwiennego uszkodzenia narzqdów. U jej podtoża leży wrodzony (wrodzona TTP) lub nabyty (nabyta TTP) niedobór osoczowej metaloproteinazy ADAMTS13 (13 przedstawiciel rodziny dezintegryn i metaloproteinaz z motywem trombospondyny typu 1). Zakrzepowa plamica matoptytkowa należy do stanów nagtych whematologii; niewtaściwie rozpoznana i nieprawidtowo leczona charakteryzuje się wysoka śmiertelnościa. Wstęne rozpoznanie choroby ustala sie na podstawie cech niedokrwiennego uszkodzenia narzqdów, niedokrwistości hemolitycznej z ujemnym odczynem Coombsa wspótistniejacej z matoplytkowościa oraz obecnościa schistocytów w rozmazie krwi obwodowej. W przypadku podejrzenia TTP konieczne jest zabezpieczenie próbki osocza na oznaczenie aktywności oraz miana inhibitora ADAMTS13, ale wdrożenie leczenia, polegajacego gtównie na transfuzji wymiennej osocza (PEX), musi nastapić jeszcze przed laboratoryjnym potwierdzeniem TTP. Jeśli stwierdzi sie aktywność ADAMTS13 ponizej 5-10\% oraz obecność przeciwciat przeciw ADAMTS13, to rozpoznaje sie nabyta TTP $i$ kontynuuje zabiegi PEX wraz ze stosowaniem immunosupresji (zwykle kortykosteroidami). Natomiast znacznie obniżona aktywność ADAMTS13 oraz nieobecność inhibitora ADAMTS13 potwierdzaja rozpoznanie wrodzonej postaci TTP. Podstawa leczenia chorych na objawowa wrodzona postać TTP jest przetaczanie świeżo mrożonego osocza.
\end{abstract}

Słowa kluczowe: zakrzepowa plamica małopłytkowa, ADAMTS13, zespół Upshaw-Schulmana, schistocyty, transfuzja wymienna osocza, immunosupresja

Hematologia 2017; 8, 1: 12-19

\section{Abstract}

Thrombotic thrombocytopenic purpura (TTP) is characterized by a triad of symptoms: thrombocytopenia, hemolytic anemia and organ dysfunction due to disturbed microcirculation. TTP is caused by severe deficiency of a plasma metalloprotease, ADAMTS13 (a disintegrin and metalloprotease with thrombospondin type 1 motifs 13) either due to congenital defects in the ADAMTS13 gene (congenital TTP) or development of autoantiobodies against ADAMTS13 (acquired TTP). Organ dysfunction is life threatening and may lead to death unless patients are immediately ap-

Adres do korespondencji: Magdalena Górska-Kosicka, Klinika Zaburzeń Hemostazy i Chorób Wewnętrznych, Instytut Hematologii i Transfuzjologii, ul. Indiry Gandhi 16, 02-776 Warszawa, tel. 2234961 08, faks 2234961 59, e-mail: magdagorska@tlen.pl 


\begin{abstract}
plied a therapy of plasma exchange (PEX). Initial diagnosis of TTP is based on clinical symptoms of ischemic organ injury, thrombocytopenia and hemolytic anemia with negative Coombs test and schistocytes in blood smear. Suspected TTP requires collection of pretreatment samples for measurement of ADAMTS3 activity and level of anti-ADAMTS13 autoantibodies. PEX should be initiated as soon as possible, even before the results of ADAMTS13 activity and anti-ADAMTS13 autoantibodies become available. ADAMTS13 activity below 5-10\% with the presence of ADAMTS13 autoantibodies confirms the diagnosis of acquired TTP and daily PEX in combination with immunosuppressive treatment (corticosteroids) should be continued. Diagnosis of congenital TTP is confirmed by low ADAMTS13 activity in the absence of autoantibodies to ADAMTS13. Congenital TTP is usually treated with infusions of fresh frozen plasma to substitute the missing enzyme.
\end{abstract}

Key words: thrombotic thrombocytopenic purpura, ADAMTS13, Upshaw-Schulman syndrome, schistocytes, plasma exchange, immunosuppression

Hematologia 2017; 8, 1:12-19

\section{Wprowadzenie}

Zakrzepowa plamica małopłytkowa (TTP, thrombotic thrombocytopenic purpura) należy do grupy chorób określanych jako mikroangiopatie zakrzepowe (TMA, thrombotic microangiopathy). U podstaw TMA leży uogólniona zakrzepica tętniczek i naczyń włosowatych, a klinicznie występuje triada objawów: małopłytkowość, niedokrwistość hemolityczna, niedokrwienne uszkodzenia narządów. Małopłytkowość wynika $z$ uwięzienia płytek $\mathrm{w}$ mikrozakrzepach, niedokrwistość $-z$ mechanicznego uszkodzenia erytrocytów przeciskających się przez wypełnione zakrzepami drobne naczynia, zaś niedokrwienie narządów $-z$ zablokowania przepływu krwi przez naczynia krwionośne, w których rozwinęły się zakrzepy [1-3].

Zakrzepową plamicę małopłytkową dzieli się na wrodzoną (cTTP, congenital TTP), wynikającą $\mathrm{z}$ mutacji $\mathrm{w}$ genie kodującym metaloproteinazę ADAMTS13 (a disintegrin and metalloprotease with thrombospondin type 1 motifs 13 [13 przedstawiciel rodziny dezintegryn i metaloproteinaz $z$ motywem trombospondyny typu 1]), zwaną zespołem Upshaw-Schulmana (USS, Upshaw-Schulman syndrome), oraz nabytą, wynikającą $z$ blokowania funkcji ADAMTS13 przez autoprzeciwciała i dlatego określaną mianem immunologicznej TTP (iTTP, immune mediated TTP). Wyróżnia się pierwotną i wtórną postać iTTP. W pierwotnej iTTP nie wykrywa się żadnej wspólistniejącej choroby, która mogłaby wyzwolić tę postać TMA. U podłoża wtórnej iTTP leżą choroby tkanki lącznej (m.in. toczeń rumieniowy układowy, reumatoidalne zapalenie stawów, zespół Sjögrena), zakażenia (m.in. cytomegalowirusem, wirusem ludzkiego niedoboru odporności), przyjmowane leki (m.in. tiklopidyna, simwastatyna, trimetoprim, pegylowany interferon) oraz stany kliniczne, na przykład ciąża [4].

\section{Epidemiologia i etiopatogeneza}

Częstość cTTP nie jest dokładnie znana, ale szacuje się, że w Europie choroba występuje u 0,5-4 osób/mln mieszkańców [5]. Natomiast iTTP rozpoznaje się z częstością 4-6 przypadków/mln osób/rok. Na iTTP najczęściej chorują osoby między 30. a 40. rokiem życia; kobiety nieco częściej niż mężczyźni (2-3:1) [2,6].

U podłoża TTP leży wrodzony lub nabyty niedobór osoczowej metaloproteinazy ADAMTS13. Rolą ADAMTS13 jest rozkład ultra dużych multimerów czynnika von Willebranda (UL-VWF, ultra large-von Wilebrand factor multimers). U osób $z$ niedoborem tego enzymu, w momencie zadziałania tak zwanych czynników wyzwalających (m.in. ciąża, infekcje, zabiegi operacyjne, przyjmowanie niektórych leków), UL-VWF wiążą się $z$ płytkami krwi (PLT, platelets), formując ubogie w fibrynę zakrzepy, które blokują przepływ krwi w naczyniach włosowatych i małych tętniczkach, zwłaszcza mózgu, serca oraz nerek. Erytrocyty, przeciskając się przez wypełnione skrzeplinami drobne naczynia krwionośne, ulegają rozfragmentowaniu na schistocyty, zwane też fragmentocytami. Uwięzienie płytek krwi w zakrzepach prowadzi do małopłytkowości [2, 6-8].

Gen ADAMTS13 jest zlokalizowany na chromosomie 9q34, zawiera 29 eksonów i koduje białko składające się z 1427 aminokwasów. Do tej pory zidentyfikowano ponad 150 mutacji tego genu prowadzących do niedoboru lub upośledzenia funkcji ADAMTS13. Najczęściej są to mutacje zmiany sensu (ok. 60\%), małe delecje i insercje 
(ok. 20\%), a także mutacje nonsensowne oraz mutacje miejsc składania eksonów (mutacje splicingowe). Wrodzona TTP dziedziczy się autosomalnie recesywnie, a chorzy $z$ objawami są homozygotami lub podwójnymi heterozygotami zmutowanych alleli. U heterozygot mutacji ADAMTS13 (rodzice lub rodzeństwo chorego) aktywność ADAMTS13 zwykle wynosi 40-70\% normy, a objawy kliniczne TMA nie występują $[5,9,10]$.

Nabyty niedobór ADAMTS13 jest spowodowany obecnością autoprzeciwciał skierowanych wobec tej metaloproteinazy. Występują dwa typy przeciwciał anty-ADAMTS13 - neutralizujące (tzw. inhibitor) i nieneutralizujące. Oba rodzaje przeciwciał mogą jednocześnie występować w iTTP. Przeciwciała neutralizujące wiążą się z ADAMTS13 i hamują jej aktywność proteolityczną. Przeciwciała nieneutralizujące, poprzez opsonizację tej metaloproteinazy lub w innym, niewyjaśnionym mechanizmie, przyspieszają jej klirens $z$ krwiobiegu, natomiast nie hamują jej aktywności. Przeciwciała nieneutralizujące obserwuje się w około $30 \%$ przypadków iTTP $[2,6,8]$.

\section{Objawy podmiotowe i przedmiotowe}

Wrodzona TTP w około połowie przypadków ujawnia się $\mathrm{w}$ dzieciństwie, rzadziej pierwsze objawy choroby występują między 20. a 40 . rokiem życia. Może się także zdarzyć bezobjawowy przebieg choroby nawet do 60. roku życia. Wrodzona TTP charakteryzuje się występowaniem ostrych ataków, które mogą być wyzwolone przez czynniki zewnętrzne (np. zakażenie, nadmierne spożycie alkoholu, ciąża). Obraz kliniczny może się różnić nawet $\mathrm{w}$ obrębie tej samej rodziny oraz wśród niespokrewnionych pacjentów $z$ tym samym typem mutacji sprawczej. U noworodków głównym objawem USS jest hiperbilirubinemia. U starszych dzieci obserwuje się izolowaną małopłytkowość lub małopłytkowość wspólistniejącą $z$ niedokrwistością hemolityczną. Objawy skazy krwotocznej występują rzadko. $Z$ czasem dołączają się objawy niedokrwiennego uszkodzenia narządów. Pierwszą manifestacją kliniczną może być udar niedokrwienny mózgu lub ostra niewydolność nerek $[1-3,10]$. Zdarza się także, że pierwsze, zauważalne objawy cTTP pojawiają się w czasie ciąży (najczęściej na przełomie II i III trymestru), a wówczas postęp choroby może być bardzo gwałtowny [11-13].

W przeciwieństwie do cTTP, iTTP występuje głównie u dorosłych. Przebieg iTTP jest często bardzo dynamiczny, a stan chorego gwałtownie się pogarsza. Choroba może się rozpoczynać gorączką.
Następnie dochodzi do niedokrwiennego uszkodzenia narządów wewnętrznych. Zazwyczaj w obrazie klinicznym dominują zaburzenia neurologiczne wynikające $z$ niedokrwienia ośrodkowego układu nerwowego (OUN). Obserwuje się bóle głowy, splątanie, afazję, dyzartię, zaburzenia widzenia, niedowłady, drgawki, a w skrajnych przypadkach śpiączkę. Niedokrwienne uszkodzenie nerek prowadzi początkowo do zmian w analizie moczu (białkomocz, hemoglobinuria), następnie dołączają się objawy niewydolności nerek pod postacią oligurii, anurii, wzrostu stężenia kreatyniny i mocznika we krwi. Mogą także występować cechy uszkodzenia mięśnia sercowego (niedokrwienie, zaburzenia rytmu, niewydolność krążenia), płuc (niewydolność oddechowa) oraz bóle brzucha związane $z$ niedokrwieniem jelit bądź trzustki. Podobnie jak w USS małopłytkowość rzadko wywoluje objawy skazy krwotocznej. Zdarzają się jednak wybroczyny, podbiegnięcia krwawe, krwawienia $z$ nosa, śluzówek jamy ustnej i przewodu pokarmowego. Hemoliza prowadzi do niedokrwistości i żółtaczki $[1,2,11]$.

\section{Diagnostyka}

W badaniach laboratoryjnych charakterystyczną cechą TTP (wrodzonej i nabytej) są obecne w rozmazie krwi obwodowej schistocyty (fragmentocyty), którymi pole widzenia jest zwykle gęsto usiane (typowo $>10 \% \mathrm{w}$ polu widzenia). W morfologii krwi stwierdza się niedokrwistość normocytową i małopłytkowość. O hemolitycznym tle niedokrwistości świadczą podwyższona liczba retikulocytów, obniżone stężenie haptoglobiny, zwiększone stężenie bilirubiny pośredniej i zwiększona aktywność dehydrogenazy mleczanowej (LDH, lactate dehydrogenase). Wzrost aktywności LDH wynika także $z$ niedokrwiennego uszkodzenia tkanek zajętych przez chorobę narządów. Odczyn antyglobulinowy (Coombsa) jest ujemny. U pacjentów $z$ uszkodzeniem nerek obserwuje się podwyższone stężenia kreatyniny i mocznika, zmiany $\mathrm{w}$ analizie moczu (białkomocz, krwinkomocz). Wyniki badań przesiewowych układu krzepnięcia krwi zazwyczaj pozostają w zakresie normy lub na granicy wartości prawidłowych [1-3]. Wyniki badań laboratoryjnych wskazujących na TTP przedstawiono w tabeli 1 .

Podejrzewając TTP, wykonuje się oznaczenia aktywności ADAMTS13 oraz stężenia inhibitora ADAMTS13. Kluczowe zarówno dla wrodzonej, jak i nabytej postaci TTP jest wykazanie ciężkiego niedoboru ADAMTS13 (< 5-10\% normy); u zdrowych osób wartości prawidłowe wynoszą 50-100\%. 
Tabela 1. Wyniki badań laboratoryjnych wskazujących na zakrzepową plamicę małopłytkową

Table 1. Laboratory test results characteristic for thrombotic thrombocytopenic purpura

\begin{tabular}{|l|c|}
\hline Rodzaj badania laboratoryjnego & Wynik \\
\hline Liczba płytek krwi & Obniżona (zwykle $<80 \mathrm{G} / \mathrm{l})$ \\
\hline Stężenie hemoglobiny & Obniżone (zwykle $<10 \mathrm{~g} / \mathrm{dl}$ ) \\
\hline Rozmaz krwi & Obecne schistocyty (zwykle $>10 \%)$ \\
\hline Liczba retikulocytów & Zwiększona \\
\hline Stężenie LDH & Obniżone \\
\hline Stężenie haptoglobiny & Zwiększone \\
\hline Stężenie bilirubiny & Często zwiększone \\
\hline Stężenie kreatyniny & Zwykle prawidłowe \\
\hline Wartości PT, APTT, fibrynogenu & Znacznie obniżona (<5-10\%) \\
\hline Aktywność ADAMTS13 & Nieobecny w cTTP \\
\hline Inhibitor ADAMTS13 & Obecny w iTTP \\
\hline
\end{tabular}

LDH (lactate dehydrogenase) - dehydrogenaza mleczanowa; PT (prothrombin time) - czas protrombinowy; APTT (activated partial thromboplastin time) - czas częściowej tromboplastyny po aktywacji; ADAMTS13 (a disintegrin and metalloprotease with thrombospondin type 1 motifs 13) - 13 przedstawiciel rodziny dezintegryn i metaloproteinaz z motywem trombospondyny typu 1; cTTP (congenital thrombotic thrombocytopenic purpura) - wrodzona zakrzepowa plamica małopłytkowa; iTTP (immune mediated thrombotic thrombocytopenic purpura) - nabyta zakrzepowa plamica małopłytkowa

U pacjentów z cTTP nie wykrywa się inhibitora ADAMTS13. W przypadku potwierdzenia rozpoznania USS aktywność ADAMTS13 powinno się zbadać u rodzeństwa chorego oraz innych krewnych pierwszego stopnia (badania rodzinne). Badaniem weryfikującym rozpoznanie cTTP $\mathrm{w}$ rodzinie jest wykrycie mutacji sprawczej w genie ADAMTS13. Natomiast diagnozę iTTP potwierdza zmniejszona aktywność ADAMTS13 (< 5-10\% normy) oraz obecność przeciwciał anty-ADAMTS13 [1, 3, 4, 7].

Należy pamiętać, aby krew do badań w kierunku niedoboru ADAMTS13 została pobrana przed rozpoczęciem leczenia (patrz nizej), gdyż w przeciwnym razie może dojść do zafałszowania wyników aktywności ADAMTS13 i miana inhibitora ADAMTS13 [14]. W przypadku braku możliwości natychmiastowego wykonania tych oznaczeń pobrany materiał należy zabezpieczyć, tj. uzyskane po odwirowaniu krwi cytrynianowej ubogopłytkowe osocze rozporcjować i zamrozić w temperaturze poniżej $-20^{\circ} \mathrm{C}$.

W praktyce klinicznej wstępne rozpoznanie TTP ustala się na podstawie obrazu klinicznego oraz obecności schistocytów i niedokrwistości hemolitycznej wspólistniejącej z małopłytkowością [1-3, 15]. Ze względu na zazwyczaj ciężki przebieg kliniczny TTP, leczenie rozpoczyna się jak najszybciej, zwykle przed uzyskaniem wyników oznaczeń aktywności ADAMTS13 i miana inhibitora ADAMTS13.

\section{Diagnostyka różnicowa}

W diagnostyce różnicowej TTP uwzględnia się inne TMA, zwłaszcza zespół hemolityczno-mocznicowy (HUS, hemolytic uremic syndrome), a także katastrofalny zespół antyfosfolipidowy, zespół rozsianego wykrzepiania wewnątrznaczyniowego, a u kobiet $\mathrm{w}$ ciąży — gestozę i zaliczany do TMA zespół HELLP (hemolysis, elevated hiver enzymes, low platelets [hemoliza, podwyższenie stężenia enzymów wątrobowych, niska liczba płytek krwi)]). Szczególnie trudna jest diagnostyka kobiet w ciąży, gdyż obraz kliniczny i wyniki wielu badań laboratoryjnych w przebiegu TTP, zespołu HELLP i zatrucia ciążowego mogą być identyczne $[2,3,12$, 13]. W tabeli 2 scharakteryzowano choroby wymagające różnicowania $z$ TTP.

\section{Leczenie}

Odróżnienie cTTP od iTTP jest możliwe tylko na podstawie wyników aktywności ADAMTS13 i miana inhibitora ADAMTS13. Jeśli nie ma potwierdzenia USS, to do momentu uzyskania niezbędnych wyników badań wdraża się leczenie jak w iTTP. Szczególnie trudne jest leczenie nieprzytomnego pacjenta, zwłaszcza jeżeli nie ma możliwości szybkiego wykonania badań obrazowych wykluczających krwawienie do OUN. Postępowaniem $z$ wyboru jest wymienna transfuzja osocza (PEX, plasma 


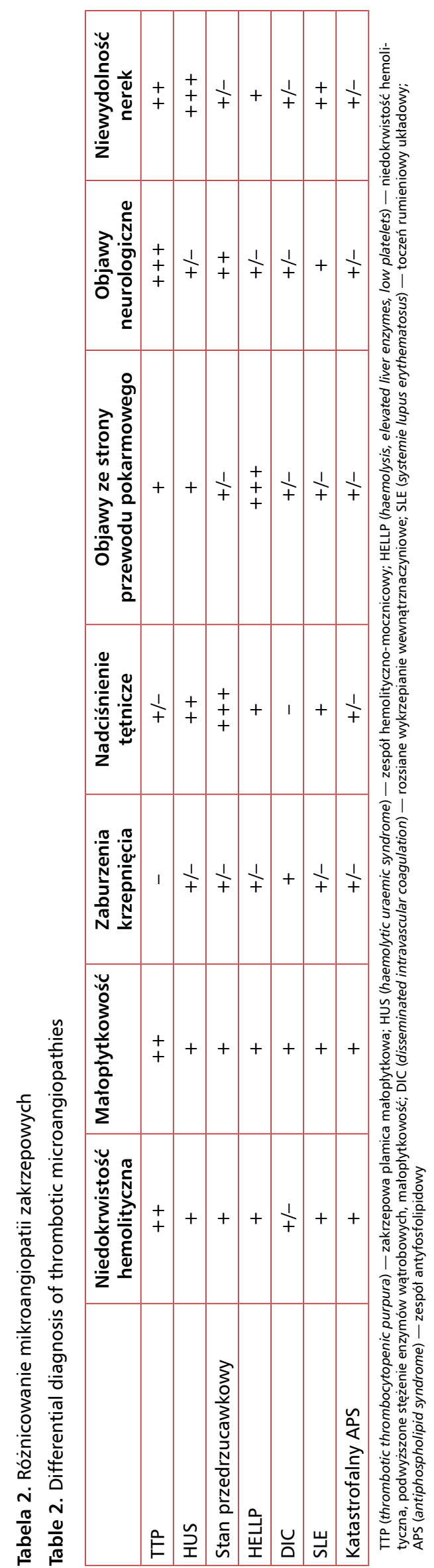

exchange), która usuwa przeciwciała przeciw ADAMTS13 i uzupełnia ADAMTS13 w podawanym osoczu pochodzącym od zdrowych dawców. Zazwyczaj rozpoczyna się od wymiany 1,5 objętości osocza raz/na dobę. Po uzyskaniu poprawy klinicznej i stabilizacji stanu pacjenta możliwa jest redukcja do 1 objętości osocza. Intensywniejszą terapię, na przykład wymianę 1,5 objętości osocza dwa razy/ /dobę, zaleca się w opornych postaciach choroby, zwłaszcza gdy w trakcie terapii postępuje uszkodzenie narządów $[3,6,15,16]$. Eksperci zalecają kontynuację plazmaferez co najmniej przez 2 dni po uzyskaniu remisji, definiowanej jako liczba PLT powyżej $150 \mathrm{G} / 1$ oraz ustąpienie objawów klinicznych choroby [3]. Jeśli nie ma możliwości natychmiastowego wykonania PEX, to jako terapię pomostową stosuje się przetoczenia świeżo mrożonego osocza (FFP, fresh frozen plasma) w możliwie największych tolerowanych przez chorego objętościach $[1,17]$. W przypadku braku powodzenia leczenia zamiast FFP można stosować osocze pozbawione krioprecypitatu, zwane kriosupernatantem [14, 15].

W celu trwałej eliminacji inhibitora przeciw ADAMTS13 kojarzy się PEX z lekami immunosupresyjnymi, w pierwszej linii z glikokortykosteroidami, na przykład metylprednizolonem $\mathrm{w}$ dawce $1,0 \mathrm{~g} /$ dobę dożylnie przez $3 \mathrm{dni}$ lub prednizonem w dawce $1 \mathrm{mg} / \mathrm{kg} \mathrm{mc}$./dobę doustnie zwykle przez 6 tygodni [3]. Jeśli mimo takiej terapii po 5 dniach plazmaferez liczba PLT wynosi poniżej $50 \mathrm{G} / \mathrm{l}$, a aktywność LDH utrzymuje się powyżej 1,5 $\times$ wartości górnej granicy normy, to rozpoznaje się oporną iTTP. Jeżeli liczba PLT utrzymuje się poniżej $30 \mathrm{G} / 1$, to chorobę określa się jako ciężką [4]. W tej grupie pacjentów można włączyć rytuksymab (RTX, rituximab). Lek ten okazał się skuteczny w leczeniu chorych na iTTP oporną na PEX w skojarzeniu $z$ glikokortykosteroidami, a także u pacjentów $z$ nawrotem choroby. Rytuksymab podaje się $\mathrm{w}$ dawce $375 \mathrm{mg} / \mathrm{m}^{2}$ dożylnie raz w tygodniu przez 4 tygodnie; u pacjentów słabo odpowiadających na leczenie można zastosować 8 dawek RTX [2, 3, 14, 15]. Niestety, stosowanie RTX w tym wskazaniu nie jest refundowane przez Narodowy Fundusz Zdrowia. W przypadku oporności na RTX lub braku jego dostępności można zastosować inne leki immunomodulujące, takie jak cyklofosfamid, cyklosporynę, winkrystynę, takrolimus czy wykonać splenektomię $[1,3,14,15,18]$. W ośrodku, w którym pracują autorzy niniejszej pracy, w takiej sytuacji stosuje się dość często pulsy cyklofosfamidu w dawce $500-700 \mathrm{mg} / \mathrm{m}^{2}$ w odstępach 7-14-dniowych (3-6 pulsów). W postaciach opornych stosowano także $z$ dobrym efektem 
bortezomib, N-acetylocysteinę i ekulizumab [14, $16,19,20]$. Dobre wyniki uzyskano po dołączeniu do PEX kaplacizumabu - cząsteczki wiążącej się $z$ domeną A1 czynnika von Willebranda i blokującej jego interakcję $z$ płytkowym receptorem glikoproteiny $\mathrm{Ib} / \mathrm{IX} / \mathrm{V}$, co zapobiega tworzeniu agregatów PLT blokujących przepływ krwi w naczyniach [14, $16,19]$.

U chorych $z$ objawową cTTP stosuje się profilaktyczne przetoczenia FFP będącego źródłem brakującego ADAMTS13. W długoterminowej profilaktyce zaostrzeń USS podaje się FFP w dawce 10-40 ml/kg mc. (w ciągu 1-4 dni) co 2-4 tygodnie $[1,14]$. Okres biologicznego półtrwania ADAMTS 13 wynosi 2-4 dni, zaś aktywność ADAMTS13 mierzona bezpośrednio po przetoczeniu $1-2 \mathrm{j}$. FFP wzrasta o $10-20 \%$, by po 3-8 dniach zmniejszyć się do poniżej 5-10\% normy [21]. Nie wyjaśniono, dlaczego $\mathrm{u}$ wielu pacjentów $z$ USS korzystny efekt kliniczny po przetoczeniu FFP utrzymuje się do 3 tygodni. Częstotliwość profilaktycznych przetoczeń ustala się empirycznie, indywidualnie u każdego pacjenta, zależnie od przebiegu klinicznego choroby. Istnieje grupa chorych, u których liczba PLT utrzymuje się przez większość czasu w normie, a zaostrzenia występują okazjonalnie, na przykład podczas infekcji, po szczepieniach, w okresie ciąży, po nadmiernym spożyciu alkoholu $[1,3,14]$. W takiej sytuacji nie podaje się FFP $\mathrm{w}$ trybie długoterminowej profilaktyki, a jedynie leczy zaostrzenia choroby. Ostre epizody USS zazwyczaj udaje się opanować, podając FFP w dawce $20-40 \mathrm{ml} / \mathrm{kg} \mathrm{mc}$. przez kilka dni [7, 14]. Mimo regularnych przetoczeń FFP u chorych na USS nie opisywano pojawiania się inhibitora przeciwko ADAMTS13, mogą się natomiast pojawiać nieneutralizujące przeciwciała klasy IgG o zmiennym mianie, których znaczenie jest nieznane [5].

W ośrodku, w którym pracują autorzy niniejszej pracy, w przypadku słabego efektu lub braku efektu po podaniu FFP stosuje się kriosupernatant. Obiecujące są wyniki badań przedklinicznych i klinicznych nad rekombinowanym ADAMTS13 [22, 23]. Obecnie lek ten znajduje się już w III fazie badań klinicznych, a jego wprowadzenie na rynek farmaceutyczny może zrewolucjonizować leczenie chorych na USS.

Pacjenci z TTP będący w ciężkim stanie ogólnym są zagrożeni wystąpieniem żylnej choroby zakrzepowo-zatorowej. Dlatego z chwilą wzrostu liczby PLT powyżej 50 G/l należy zastosować tromboprofilaktykę farmakologiczną — najczęściej włącza się heparynę drobnocząsteczkową $[1,3,14$, $15,17]$. U chorych $z$ ciężkim niedokrwieniem
OUN lub mięśnia sercowego w celu poprawy perfuzji można rozważyć zastosowanie małych dawek kwasu acetylosalicylowego, pod warunkiem że liczba PLT przekracza $50 \mathrm{G} / 1$ i nie obserwuje się skłonności do krwawień [2, 3, 12, 19].

U pacjentów $z$ TTP przetoczenie koncentratu krwinek płytkowych może nasilić powstawanie zakrzepów, dlatego tylko krwawienie zagrażające życiu usprawiedliwia sięgnięcie po tę opcję terapeutyczną. $Z$ kolei wskazaniem do przetaczania koncentratu krwinek czerwonych jest głęboka niedokrwistość i objawy kliniczne $z$ niej wynikające $[1,3,15,17]$. W okresie aktywnej hemolizy podaje się kwas foliowy.

Od czasu wprowadzenia PEX śmiertelność w przebiegu iTTP zmniejszyła się z $80-90 \%$ do 10-20\%, ale opóźnienie jej zastosowania znacznie pogarsza rokowanie [2]. U $21 \%$ chorych, którzy osiągnęli remisję (ustąpienie objawów klinicznych choroby i normalizacja liczby PLT), dochodzi do nawrotu choroby, a przetrwała obniżona aktywność ADAMTS13 stanowi jego główny czynnik ryzyka $[4,17]$.

W przypadku USS nie ma leczenia przyczynowego. Przebieg choroby jest zróżnicowany - obserwuje się zarówno pacjentów niewymagających leczenia, jak i pacjentów, u których mimo regularnych, częstych przetoczeń FFP występują zaostrzenia choroby [5].

\section{Zakrzepowa plamica małopłytkowa u kobiet w ciąży}

Ta postać TMA wymaga odrębnego omówienia. W okresie ciąży może się ujawnić po raz pierwszy zarówno cTTP, jak i iTTP [15]. Ocenia się, że ciąża jest czynnikiem inicjującym 5-25\% wszystkich wykrywanych przypadków TTP [3]. Powstające w naczyniach łożyska zakrzepy mogą prowadzić do obumarcia płodu i objawów zatrucia ciążowego. Różnicowanie ze stanem przedrzucawkowym, zespołem HELLP i HUS jest trudne. Aktywność ADAMTS13 bywa obniżona u kobiet $z$ zespołem HELLP, stanem przedrzucawkowym i HUS, ale praktycznie zawsze wynosi powyżej 5-10\% normy [3, 12, 13, 15].

Leczenie kobiet w ciąży z TTP wymaga wspó1pracy ginekologa i hematologa. Podejrzenie TTP (niedokrwistość hemolityczna $z$ ujemnym odczynem Coombsa i z obecnością schistocytów, małopłytkowość, objawy niedokrwiennego uszkodzenia narządów) jest wskazaniem do natychmiastowego rozpoczęcia PEX do momentu ewentualnego wykluczenia iTTP i potwierdzenia cTTP. 
Plazmaferezy wykonuje się w skojarzeniu z podawaniem glikokortykosteroidów [7, 12, 15]. Postępowaniem $z$ wyboru jest rozwiązanie ciąży, które wykonuje się w momencie osiagnięcia przez płód zdolności do samodzielnego życia. Zakończenie ciąży nie zawsze wiąże się $z$ remisją TTP i nie zwalnia od dalszej obserwacji pacjentki i kontynuacji stosowania odpowiedniej dla niej terapii.

W przypadku wcześniej rozpoznanego USS już w 8.-10. tygodniu ciąży wdraża się profilaktyczną suplementację ADAMTS13 za pomocą przetoczeń FFP w dawce $10 \mathrm{ml} / \mathrm{kg}$ mc. co 2-4 tygodnie. Można także włączyć małe dawki kwasu acetylosalicylowego $[3,12,15]$. Jeśli liczba PLT obniży się poniżej $150 \mathrm{G} / \mathrm{L}$, to leczenie należy intensyfikować. U kobiet $\mathrm{w}$ ciąży $\mathrm{z}$ TTP wskazana jest także regularna ocena przepływu w naczyniach łożyska metodą ultrasonografii doplerowskiej [12].

\section{Podsumowanie}

Zważywszy na dynamiczny przebieg i wysoką śmiertelność w przypadku opóźnienia leczenia, TTP to stan naglący w hematologii. Rozpoznanie wstępne ustala się na podstawie obrazu klinicznego (niedokrwienne uszkodzenie narządów) oraz stwierdzenia schistocytów w rozmazie krwi obwodowej, niedokrwistości hemolitycznej z ujemnym odczynem Coombsa i małopłytkowości. Kolejnym krokiem jest zabezpieczenie próbki na oznaczenie aktywności ADAMTS13 oraz miana inhibitora wobec ADAMTS13 i natychmiastowe, tj. przed uzyskaniem wyników badań, wdrożenie transfuzji wymiennej osocza, najczęściej w skojarzeniu z glikokortykosteroidami. Jeśli wyjściowa aktywność ADAMTS13 jest obniżona poniżej 5-10\% i wykrywa się przeciwciała przeciw tej metaloproteinazie, to rozpoznaje się iTTP i kontynuuje wyżej opisane leczenie. Dla iTTP charakterystyczny jest bardziej dynamiczny przebieg i zazwyczaj starszy wiek pacjenta $\mathrm{w}$ porównaniu $z$ USS. Natomiast obniżona aktywność ADAMTS13 przy ujemnym wyniku badania w kierunku inhibitora ADAMTS13 wskazuje na wrodzoną postać TTP i - zależnie od przebiegu klinicznego - stanowi wskazanie do przetoczeń FFP.

\section{Piśmiennictwo}

1. Knöbl P. Inherited and acquired thrombotic thrombocytopenic purpura (TTP) in adults. Semin Thromb Hemost. 2014; 40(4): 493-502, doi: 10.1055/s-0034-1376883, indexed in Pubmed: 24802084 .

2. Tsai HM. Thrombotic thrombocytopenic purpura, hemolytic-uremic syndrome and related disorders. In: Greer JP, Foerster JM,
Rodgers G. et. al. ed. Wintrobe's clinical hematology, $13^{\text {th }}$ edition. Wolters Kluwer, Lippincott, Williams and Wilkins, Philadelphia 2014: 1077-1094.

3. Scully M, Hunt BJ, Benjamin S, et al. British Committee for Standards in Haematology. Guidelines on the diagnosis and management of thrombotic thrombocytopenic purpura and other thrombotic microangiopathies. Br J Haematol. 2012; 158(3): 323-335, doi: 10.1111/j.13652141.2012.09167.x, indexed in Pubmed: 22624596.

4. Scully M, Cataland S, Coppo P, et al. International Working Group for Thrombotic Thrombocytopenic Purpura. Consensus on the standardization of terminology in thrombotic thrombocytopenic purpura and related thrombotic microangiopathies. J Thromb Haemost. 2017; 15(2): 312-322, doi: 10.1111/jth.13571, indexed in Pubmed: 27868334.

5. Mansouri Taleghani M, von Krogh AS, Fujimura Y, et al. Hereditary thrombotic thrombocytopenic purpura and the hereditary TTP registry. Hämostaseologie. 2013; 33(2): 138-143, doi: 10.5482/HAMO-13-04-0026, indexed in Pubmed: 23715103.

6. Lämmle B, Kremer Hovinga JA, Alberio L. Thrombotic thrombocytopenic purpura. J Thromb Haemost. 2005; 3(8): 1663-1675, doi: 10.1111/j.1538-7836.2005.01425.x, indexed in Pubmed: 16102032.

7. Shah N, Rutherford C, Matevosyan K, et al. Role of ADAMTS13 in the management of thrombotic microangiopathies including thrombotic thrombocytopenic purpura (TTP). Br J Haematol. 2013; 163(4): 514-519, doi: 10.1111/bjh.12569, indexed in Pubmed: 24111495.

8. Peyvandi F, Palla R, Lotta LA, et al. ADAMTS-13 assays in thrombotic thrombocytopenic purpura. J Thromb Haemost. 2010; 8(4): 631-640, doi: 10.1111/j.1538-7836.2010.03761.x, indexed in Pubmed: 20088924.

9. Tsai HM, Tsai HM, Manea M, et al. Pathophysiology of thrombotic thrombocytopenic purpura. Int J Haematol. 2010; 91(1): 1-19, doi: 10.1007/s12185-009-0476-1, indexed in Pubmed: 20058209.

10. Hassenpflug WA, Budde U, Schneppenheim S, et al. Inherited thrombotic thrombocytopenic purpura in children. Semin Thromb Hemost. 2014; 40(4): 487-492, doi: 10.1055/s-0034-1376152, indexed in Pubmed: 24816970.

11. George JN, Nester CM, McIntosh JJ, et al. Syndromes of thrombotic microangiopathy. N Engl J Med. 2014; 371(7): 654-666, doi: 10.1056/NEJMra1312353, indexed in Pubmed: 25119611.

12. Savignano C, Rinaldi C, De Angelis V. Pregnancy associated thrombotic thrombocytopenic purpura: Practical issues for patient management. Transfus Apher Sci. 2015; 53(3): 262-268, doi: 10.1016/j.transci.2015.11.005, indexed in Pubmed: 26626962.

13. Pourrat O, Coudroy R, Pierre F. Differentiation between severe HELLP syndrome and thrombotic microangiopathy, thrombotic thrombocytopenic purpura and other imitators. Eur J Obstet Gynecol Reprod Biol. 2015; 189: 68-72, doi: 10.1016/j. ejogrb.2015.03.017, indexed in Pubmed: 25879992.

14. Knöbl PN. Treatment of thrombotic microangiopathy with a focus on new treatment options. Hämostaseologie. 2013; 33(2): 149-159, doi: 10.5482/HAMO-13-01-0004, indexed in Pubmed: 23715105.

15. Blombery P, Scully M. Management of thrombotic thrombocytopenic purpura: current perspectives. J Blood Med. 2014; 5: 15-23, doi: 10.2147/JBM.S46458, indexed in Pubmed: 24523598.

16. Coppo P. French Reference Center for Thrombotic Microangiopathies. Treatment of autoimmune thrombotic thrombocytopenic purpura in the more severe forms. Transfus Apher Sci. 2017; 56(1): 52-56, doi: 10.1016/j.transci.2016.12.019, indexed in Pubmed: 28110841. 
17. Kessler CS, Khan BA, Lai-Miller K. Thrombotic thrombocytopenic purpura: a hematological emergency. J Emerg Med. 2012; 43(3): 538-544, doi: 10.1016/j.jemermed.2012.01.027, indexed in Pubmed: 22445678.

18. Sayani FA, Abrams CS. How I treat refractory thrombotic thrombocytopenic purpura. Blood. 2015; 125(25): 3860-3867, doi: 10.1182/ /blood-2014-11-551580, indexed in Pubmed: 25784681.

19. Cataland SR, Wu HM. Acquired thrombotic thrombocytopenic purpura: new therapeutic options and their optimal use. J Thromb Haemost. 2015; 13(Suppl 1): S223-S229, doi: 10.1111/jth.12934, indexed in Pubmed: 26149028.

20. Patriquin CJ, Thomas MR, Dutt T, et al. Bortezomib in the treatment of refractory thrombotic thrombocytopenic purpura. $\mathrm{Br} \mathrm{J} \mathrm{Ha}-$ ematol. 2016; 173(5): 779-785, doi: 10.1111/bjh.13993, indexed in Pubmed: 27009919.
21. Kremer Hovinga JA, Lämmle B. Role of ADAMTS13 in the pathogenesis, diagnosis, and treatment of thrombotic thrombocytopenic purpura. Hematology Am Soc Hematol Educ Program. 2012; 2012: 610-616, doi: 10.1182/asheducation-2012.1.610, indexed in Pubmed: 23233642.

22. Kopić A, Benamara K, Piskernik C, et al. Preclinical assessment of a new recombinant ADAMTS-13 drug product (BAX930) for the treatment of thrombotic thrombocytopenic purpura. J Thromb Haemost. 2016; 14(7): 1410-1419, doi: 10.1111/jth.13341, indexed in Pubmed: 27371116.

23. Scully M, Knöbl P, Kentouchem K, et al. Blood. Pharmacodynamic profile of a recombinant ADAMTS13 (BAX930) in hereditary thrombotic thrombocytopenic purpura (Upshaw-Schulman Syndrome (USS)). 2016; 128: 135. 